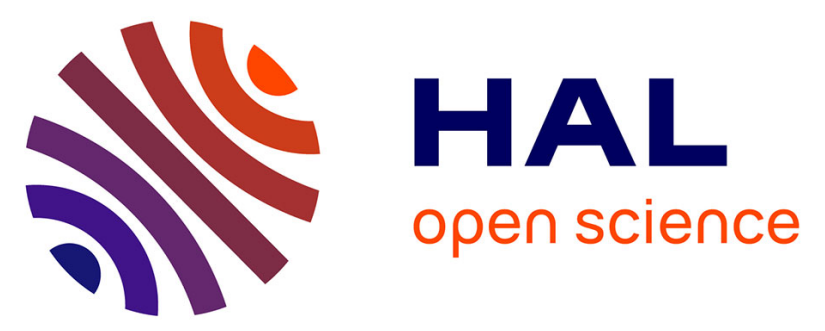

\title{
Structure and Function of Adsorbed Hemoglobin on Silica Nanoparticles: Relationship between the Adsorption Process and the Oxygen Binding Properties
}

Stéphanie Devineau, Loussiné Zargarian, Jean-Philippe Renault, Serge Pin

\section{- To cite this version:}

Stéphanie Devineau, Loussiné Zargarian, Jean-Philippe Renault, Serge Pin. Structure and Function of Adsorbed Hemoglobin on Silica Nanoparticles: Relationship between the Adsorption Process and the Oxygen Binding Properties. Langmuir, 2017, 33, pp.3241 - 3252. 10.1021/acs.langmuir.6b04281 . cea-01510273

\section{HAL Id: cea-01510273 \\ https://hal-cea.archives-ouvertes.fr/cea-01510273}

Submitted on 19 Apr 2017

HAL is a multi-disciplinary open access archive for the deposit and dissemination of scientific research documents, whether they are published or not. The documents may come from teaching and research institutions in France or abroad, or from public or private research centers.
L'archive ouverte pluridisciplinaire HAL, est destinée au dépôt et à la diffusion de documents scientifiques de niveau recherche, publiés ou non, émanant des établissements d'enseignement et de recherche français ou étrangers, des laboratoires publics ou privés.

\section{(c)(1)}

Distributed under a Creative Commons Attribution| 4.0 International License 


\title{
Structure and function of adsorbed hemoglobin on
}

\author{
silica nanoparticles: relationship between the
}

\section{adsorption process and the oxygen binding}

\section{properties}

Stéphanie Devineau ${ }^{a, \#, *}$, Loussiné Zargarian $^{b}$, Jean Philippe Renault ${ }^{a}$, Serge Pin ${ }^{a}$

${ }^{a}$ LIONS, NIMBE, CEA, CNRS, Université Paris-Saclay, CEA Saclay, 91191 Gif-sur-Yvette, France

${ }^{\mathrm{b}}$ LBPA, ENS de Cachan, CNRS, Université Paris-Saclay, 94235 Cachan Cedex, France

KEYWORDS: Adsorption; porcine hemoglobin; silica nanoparticles; protein structure; oxygenation; cooperativity.

ABSTRACT. The connection between the mechanisms of protein adsorption on nanoparticles and the structural and functional properties of the adsorbed protein often remains unclear. We investigate porcine hemoglobin adsorption on silica nanoparticles and we analyze the structural and functional modifications of adsorbed hemoglobin by UV-vis spectrophotometry, circular dichroism and oxygen binding measurement. The structural analysis of adsorbed hemoglobin on silica nanoparticles reveals a significant loss of secondary structure and a preservation of the heme electronic structure. However, adsorbed hemoglobin retains its quaternary structure and exhibits an enhanced oxygen affinity with cooperative binding. Moreover, the structural and functional modifications are fully reversible after complete desorption from silica nanoparticles at $\mathrm{pH}$ 8.7. The tunable adsorption and desorption of hemoglobin on SNPs with $\mathrm{pH}$ change, and 
the full control of hemoglobin activity by $\mathrm{pH}$, temperature and the addition of inorganic phosphate effectors opens the way to an interesting system whereby protein adsorption on nanoparticles can allow for full control over hemoglobin oxygen binding activity. Our results suggest that adsorption of hemoglobin on silica nanoparticles leads to a new structural, functional and dynamic state with full reversibility in a way that significantly differs from protein denaturation.

\section{TEXT}

\section{Introduction}

Nanotechnology has the potential to revolutionize numerous aspects of our daily life. Engineered nanomaterials (NMs) have become technological and economic stakes ${ }^{1-4}$ for a wide range of applications, such as construction, plastic processing, fabrics, and energy ${ }^{5-7}$. The biological applications of NMs are expanding in food industry, cosmetics, pharmacology and medicine, covering a number of different uses from antimicrobial coating and targeted drug delivery to material biocompatibility and imaging ${ }^{8-10}$. In particular, the rapid growth of nanomedicine has seen a large set of NMs being investigated to evaluate their potential as drug carriers, vaccine adjuvants, biocompatible implants or diagnostic probes ${ }^{11-13}$. The number of products containing NMs has been multiplied by five between 2006 and 2011 and over 1800 products containing NMs have been produced in $2014^{14,15}$.

Simultaneously, the field of nanotoxicology has significantly developed to investigate the risks and the impacts of NM exposure on the environment and health ${ }^{16-22}$. The assessment of NM toxicity has involved substantial evolutions in the field to deal with the specific interactions of NMs with biological systems. The understanding of the formation of the protein corona and its

key role as an interface between biological systems and NMs has been an essential step ${ }^{23-26}$. 
Indeed, the adsorption of biomolecules on the surface of NMs in the biological medium leads to the formation of a complex and dynamic corona, giving NMs their 'biological identity' ${ }^{27,28}$. The protein corona determines the NM uptake and its biological outcome ${ }^{29-31}$. Moreover, the control of the conformation and the activity of the adsorbed proteins is necessary to achieve good material biocompatibility ${ }^{32,33}$. A better understanding of the molecular interactions between NMs, defined by their physical and chemical properties, and endogenous proteins likely to adsorb on the surface is thus essential to study and predict their biological effects and to design NMs with excellent biocompatibility ${ }^{34,35}$.

It has been known for a long time that protein adsorption on flat surfaces can result in a modification of the protein structure and activity ${ }^{36,37}$. Similarly, protein adsorption on NMs can impair protein structure and function ${ }^{38,39}$. The control of the protein functional state is particularly important when designing hemoglobin-loaded nanoparticles as blood substitutes ${ }^{40}$. However, the relationship between the NM properties and the adsorbed protein structure, dynamics and activity is still poorly understood. Based on the adsorption of model proteins on hydrophobic and hydrophilic particles, Norde and co-workers developed a model to predict protein adsorption as a function of protein charge and structural stability ${ }^{41,42}$. According to this model, adsorption on a hydrophilic surface is driven by electrostatic forces and the structural modifications of the adsorbed proteins. Structural rearrangements would significantly contribute to the adsorption of 'soft proteins' with a lower internal stability compared to 'hard proteins' with a strong internal stability ${ }^{36,37}$. The main interactions and driving forces of protein adsorption were described by Czeslik ${ }^{43}$. More recently, we have developed a strategy to determine the physico-chemical determinants of protein adsorption based on the identification of the adsorbed and non-adsorbed proteins in a mixture of hundreds of proteins, and on the 
statistical comparison of the structural features of each group ${ }^{44}$. This approach revealed the molecular bases of protein adsorption on silica nanoparticles (SNPs), that is an enrichment in basic residues (particularly Arg) and a low content in aromatic residues (Phe, Trp, Tyr, and His). The protein adsorption is thus correlated to the protein flexibility and ability to spread on the surface.

Protein adsorption on nanoparticles is often associated to a partial loss of secondary structure $36,38,45-47$, even if helix formation has also been observed in some cases ${ }^{48}$. The structural modifications depend on the size, shape and surface chemistry of the $\mathrm{NMs}^{38,45}$. Moreover, protein adsorption can be used to promote enzyme stability in bioreactors and biosensors for industrial applications ${ }^{49-51}$. The enzymatic activity can be decreased, increased or can remain constant after adsorption ${ }^{36,39,45,52,53}$, highlighting the complex relationship between the structural and the functional modifications of adsorbed proteins. In Norde's model, structural rearrangement contributes to protein adsorption by leading to an increase of the degree of freedom of the polypeptide chain and finally to an increase in protein flexibility ${ }^{42}$. In this model, the protein structure loss would lead to a favourable gain in entropy ${ }^{43}$. However, few experimental studies have been performed to investigate protein dynamics on surfaces despite its importance in biological processes. Recent studies rather suggest that protein adsorption can result in a decrease of the adsorbed protein dynamics ${ }^{54,55}$. Using elastic and inelastic neutron scattering experiments, we showed that myoglobin adsorption on SNPs leads to a decrease of protein flexibility and to a depletion in low frequency modes, suggesting that the structural loss of the adsorbed protein may not be the entropic driving force of adsorption ${ }^{47}$. The aim of this study is to investigate the modifications of hemoglobin structure and activity after adsorption on SNPs in connection with our results on the dynamics of adsorbed myoglobin 
47. SNPs are produced and used at an industrial scale, especially in food products. In this study, we used SNPs as a model hydrophilic inorganic surface ${ }^{56}$. Hemoglobin and myoglobin belong to the same family of hemoproteins. Hemoglobin has several advantages as a model protein: its biochemical and structural properties are well characterized; and its function of oxygen binding is particularly well suited to study its activity after adsorption. Indeed, it does not involve any substrate or cofactor that may interact with the SNPs during the reaction, contrary to most enzymatic reactions, preventing any interference during the experimental measurement of the

protein activity ${ }^{30,57}$. We investigated the mechanisms of hemoglobin adsorption on SNPs and we analysed the effect of the structural rearrangement on the surface on the activity of hemoglobin. Our results suggest that adsorption leads to a new state characterized by specific structural and functional features with full reversibility, in a way that significantly differs from protein denaturation.

\section{Methods}

Hemoglobin. Porcine hemoglobin (Sus scrofa domesticus) was purified in the oxygenated form $\left(\mathrm{HbO}_{2}\right)$ from fresh blood following standard preparation ${ }^{58}$ using erythrocyte membrane precipitation in $0.28 \mathrm{M}$ Phosphate $\mathrm{pH} 7.0 . \mathrm{HbO}_{2}$ solution was extensively dialyzed against pure water at $4^{\circ} \mathrm{C}$, stripped by passing hemoglobin desalted solution through a mixed-bed ionexchange resin (AG 501-X8 from Bio-Rad) to remove naturally bound 2,3-diphosphoglycerate (DPG) ${ }^{59}$ and centrifuged at $20,000 \mathrm{~g}$ for $10 \mathrm{~min} . \mathrm{HbO}_{2}$ concentration expressed as heme molar concentration was measured on a Shimadzu UV-2450 spectrophotometer taking $\varepsilon_{576 \mathrm{~nm}}=15,150$ $\mathrm{M}^{-1} . \mathrm{cm}^{-1}{ }^{60}$. Possible iron oxidation and potential protein damages were systematically screened by measuring the absorbance ratio at $576 \mathrm{~nm}$ and $541 \mathrm{~nm}$. 
Chemicals. BisTris-HCl, Tris- $\mathrm{HCl}$ and Phosphate buffers were prepared at a concentration of 0.1 M by dissolution of BisTris (Sigma-Aldrich B9754), Tris (Sigma-Aldrich T6066), monosodium phosphate (Sigma-Aldrich 71649) and disodium phosphate (Fisher Scientific S3720). 2,3diphosphoglycerate (DPG) (Sigma-Aldrich D5764) and inositol hexaphosphate (IHP) (SigmaAldrich P0109) were dissolved in 0.1 M BisTris-HCl pH 6.0. To avoid DPG hydrolysis, a fresh solution was prepared before each oxygen binding experiment.

Silica nanoparticles. As explained in the introduction, SNPs (Sigma-Aldrich 637238) come from the same batch as in our previous studies ${ }^{44}$ and were extensively characterized. Their mean diameter is $26 \pm 2 \mathrm{~nm}$ and their surface area is $170 \mathrm{~m}^{2} / \mathrm{g}$. SNPs were suspended in buffered solutions and vortexed for $1 \mathrm{~min}$. Small aggregates of $50 \pm 2 \mathrm{~nm}$ formed in solution. $\zeta$-potential. Zeta potential $(\zeta)$ of SNPs was measured at $25^{\circ} \mathrm{C}$ on a Zetasizer Nano-ZS (Malvern Instruments) in $0.1 \mathrm{M}$ BisTris-HCl pH 6.0, Phosphate $\mathrm{pH} 7.4$ and Tris-HCl $\mathrm{pH}$ 8.7. SNP concentration is $0.1 \mathrm{mg} / \mathrm{mL}$. Each measurement was repeated 5 times. The $\zeta$-potential was calculated by fitting the electrophoretic mobility with the Smoluchowski model. Adsorption isotherms and protein desorption. Adsorption isotherms of $\mathrm{HbO}_{2}$ on SNPs were measured by the depletion method ${ }^{47}$. $\mathrm{HbO}_{2}$ solution was added to SNP suspension with a final SNP concentration of $4.5 \mathrm{mg} / \mathrm{mL}$ and smoothly mixed overnight at $20^{\circ} \mathrm{C}$. The sample was then centrifuged at 20,000 g for $10 \mathrm{~min}$. $\mathrm{HbO}_{2}$ concentration in the supernatant was measured by spectrophotometry. The amount of adsorbed protein is expressed as $\mathrm{mg} / \mathrm{m}^{2}$. An uncertainty of $5 \%$ on the amount of adsorbed protein was determined by repeating 5 times this procedure. Protein desorption was measured after incubation of $50 \mu \mathrm{M} \mathrm{HbO}_{2}$ with SNPs at a concentration of $34 \mathrm{mg} / \mathrm{mL}$ overnight. The solution was centrifuged at 20,000 $\mathrm{g}$ for $10 \mathrm{~min}$ and the supernatant removed. The SNPs were resuspended in the leaching solution by smooth mixing at $20^{\circ} \mathrm{C}$, before 
centrifugation at 20,000 g for $10 \mathrm{~min}$ and measurement of $\mathrm{HbO}_{2}$ concentration in the supernatant. To avoid harsh $\mathrm{pH}$ change when adding the leaching solution, an additional experiment was performed by dialysis in $0.1 \mathrm{M}$ Tris- $\mathrm{HCl}$ buffer at $\mathrm{pH} 8.7$ at $4^{\circ} \mathrm{C}$ overnight using a Spectra/Por membrane with a $50 \mathrm{kDa}$ cut-off. All the measurements were done in triplicate.

Structural analysis. UV-visible spectra were recorded in 1-cm path length quartz cell from 250 to $800 \mathrm{~nm}$ at $25^{\circ} \mathrm{C}$ on a Shimadzu UV-2450 spectrophotometer equipped with an integrating sphere module. Circular dichroism spectra were recorded from 190 to $260 \mathrm{~nm}$ in 1-mm path length cell at $25^{\circ} \mathrm{C}$ on a Jobin-Yvon CD6 dichrograph. To minimize UV absorption by the buffers, $\mathrm{HbO}_{2}$ spectra were recorded in $0.01 \mathrm{M}$ BisTris- $\mathrm{HCl}$, Tris- $\mathrm{HCl}$ and Phosphate. Final $\mathrm{HbO}_{2}$ concentration was $10 \mu \mathrm{M}$ and SNP concentration was $6.8 \mathrm{mg} / \mathrm{mL}$. Each spectrum is the average of 4 measurements after baseline correction. The CD spectra of the solutions containing $\mathrm{HbO}_{2}$ and SNPs were baseline corrected with the SNP solution. However, no signal was recorded for SNP solutions in these conditions. To control that no particle deposition occurred during the measurement, the absorbance at $280 \mathrm{~nm}$ was recorded before and after the acquisition of the CD spectrum. No evolution was observed. The alpha-helical content $f_{\alpha}$ was first determined from the ellipticity value at $222 \mathrm{~nm}$ according to eq. $1^{61}$.

$$
f_{\alpha}=\Delta \varepsilon(222 \mathrm{~nm}) \cdot \frac{2340}{30300}
$$

The circular dichroism spectra were then fully deconvoluted using CDNN software (Applied Physics) ${ }^{62}$. All the $\mathrm{CD}$ analyses were done in triplicate and a single representative spectrum corresponding to one sample scanned 4 times is shown.

Oxygen binding curves. $\mathrm{HbO}_{2}$ at a concentration of $50 \mu \mathrm{M}$ was smoothly mixed overnight with SNPs at a concentration of $34 \mathrm{mg} / \mathrm{mL}$ in $0.1 \mathrm{M}$ BisTris-HCl, Tris- $\mathrm{HCl}$ or Phosphate. Oxygen binding was measured in a tonometer by spectrophotometry at $25^{\circ} \mathrm{C}$ and at $37^{\circ} \mathrm{C}^{63} . \mathrm{HbO}_{2}$ was 
deoxygenated under an argon flow that bubbled in pure water to prevent drying. Oxygen binding was recorded by following the absorption at $576 \mathrm{~nm}$. No desorption of hemoglobin from SNPs was observed during deoxygenation at $\mathrm{pH} 6.0$ and at $\mathrm{pH}$ 7.4. All the measurements were done in triplicate.

\section{Results}

\subsection{Monitoring $\mathrm{HbO}_{2}$ adsorption with $\mathrm{pH}$}

The adsorption of hemoglobin on SNPs was quantified by the depletion method where the concentration of free protein is measured in the supernatant. However, the red color of $\mathrm{HbO}_{2}$ allows for the direct observation of protein adsorption (Fig. 1A). Indeed, two markedly different behaviors were observed. The red pellet and transparent supernatant indicate strong protein adsorption in BisTris- $\mathrm{HCl}$ at $\mathrm{pH}$ 6.0, whereas the white pellet and red supernatant indicate little or no adsorption in Tris- $\mathrm{HCl}$ at $\mathrm{pH}$ 8.7. This observation was further confirmed by the measurement of the adsorption isotherms in BisTris- $\mathrm{HCl} \mathrm{pH}$ 6.0, in Phosphate $\mathrm{pH} 7.4$ and in Tris-HCl pH 8.7 (Fig. 1B). The maximum amount of adsorbed $\mathrm{HbO}_{2}, m_{a d s}$, is high at $\mathrm{pH} 6.0$ $\left(m_{a d s}=0.41 \pm 0.02 \mathrm{mg} / \mathrm{m}^{2}\right)$ and at $\mathrm{pH} 7.4\left(m_{a d s}=0.34 \pm 0.02 \mathrm{mg} / \mathrm{m}^{2}\right)$, and null at $\mathrm{pH} 8.7$. 

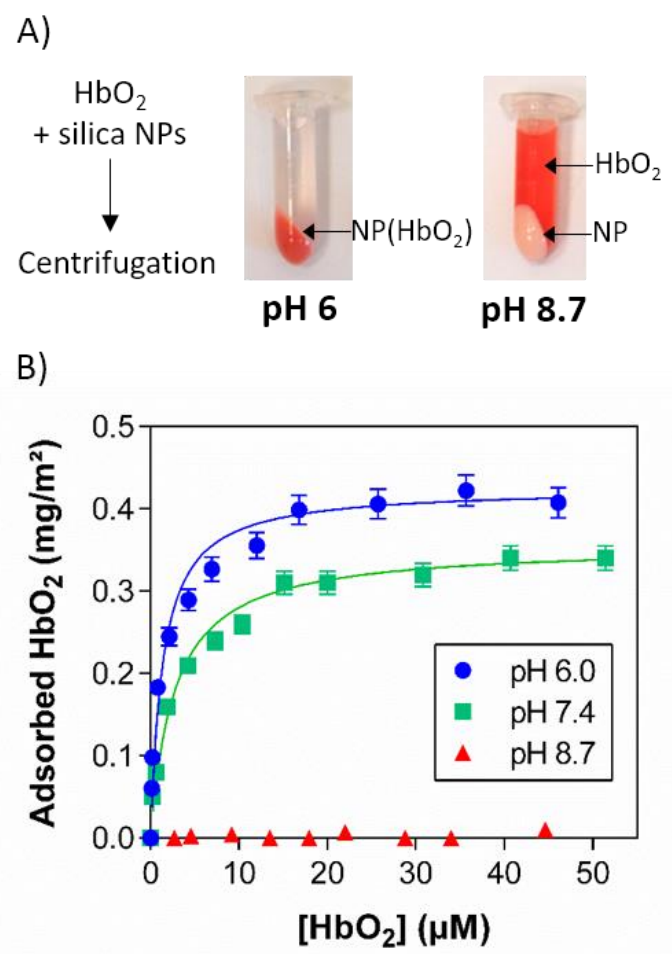

Figure 1. Adsorption behavior of $\mathrm{HbO}_{2}$ on SNPs. A) Images, after centrifugation, of $\mathrm{HbO}_{2}$ solution mixed with SNPs in $0.1 \mathrm{M}$ BisTris- $\mathrm{HCl} \mathrm{pH} 6.0$ or Tris- $\mathrm{HCl} \mathrm{pH} 8.7$; B) Adsorption isotherms of $\mathrm{HbO}_{2}$ on SNPs in $0.1 \mathrm{M}$ BisTris- $\mathrm{HCl} \mathrm{pH} 6.0$ (circle), Phosphate $\mathrm{pH} 7.4$ (square) and Tris-HCl pH 8.7 (triangle). Fitting by the Langmuir model is represented by solid lines. The adsorption constant $K_{a d s}$ which reflects the affinity of the protein for the surface was calculated by fitting the adsorption isotherms with the Langmuir model ${ }^{64}$ according to eq. 2 (Fig. 1B).

$$
m_{a d s}=\frac{m_{\infty} * K_{a d s} * C}{1+K_{a d s} * C}
$$

Where $C$ is the protein concentration at equilibrium and $m_{\infty}$ the maximum amount of adsorbed protein. The Langmuir equation is valid for the reversible adsorption of a monolayer of noninteracting molecules on a surface with identical binding sites. Since protein adsorption often results in irreversible binding to the surface, the validity of the Langmuir model to depict protein 
adsorption has been discussed in the literature ${ }^{65-67}$. In the case of hemoglobin, the plateau value clearly indicates monolayer adsorption on the surface (see §3.5).

The very different adsorption behavior at $\mathrm{pH} 6.0$ and at $\mathrm{pH} 8.7$ suggests a strong effect of charges on the adsorption of $\mathrm{HbO}_{2}$ on SNPs. The surface chemistry of amorphous SNPs in aqueous solution is characterized by the hydroxylation of the surface leading to a surface coverage by silanol groups ( $\mathrm{Si}-\mathrm{OH}$ ) of $4.6-4.9 \mathrm{OH} / \mathrm{nm}^{2}{ }^{68}$. The extent of ionization of the silanol groups in siloxide ( $\mathrm{Si}^{-} \mathrm{O}^{-}$) that gives its negative charge to SNPs at neutral $\mathrm{pH}$ depends on the size of the particles and on the ionic strength ${ }^{69,70}$. The surface charge density increases when SNP size decreases and when the ionic strength increases. In our study, the negative charge of SNPs in the different buffers was confirmed by measuring the $\zeta$-potential of the particles highlighting the increase in surface charge density with $\mathrm{pH}$ (Table S1).

The adsorption behavior of hemoglobin on SNPs as a function of $\mathrm{pH}$ was further investigated by measuring the adsorption isotherms from $\mathrm{pH} 6.0$ to 7.8 in BisTris- $\mathrm{HCl}$, from $\mathrm{pH} 7.0$ to 7.8 in Phosphate and from $\mathrm{pH} 7.2$ to 8.7 in Tris- $\mathrm{HCl}$ (Fig. 2A). The porcine $\mathrm{HbO}_{2}$ tetramer is structurally similar to that of human oxyhemoglobin ${ }^{71}$ and its global isoelectric point is around $7.2^{60}$. The amount of adsorbed $\mathrm{HbO}_{2}$ represented for each condition in Fig. 2B reveals a maximum level of adsorption from $\mathrm{pH} 6.2$ to $\mathrm{pH} 7.3$ both in BisTris- $\mathrm{HCl}$ and Tris-HCl, followed by a sharp decrease from $\mathrm{pH} 7.3$ to $\mathrm{pH} 8.5$ until zero adsorption. We can notice that for $\mathrm{pH}>7.2$, the adsorption isotherms do not reach a plateau in this concentration range. Thus, the maximum amount of adsorbed $\mathrm{HbO}_{2}$ indicated in Fig. $2 \mathrm{~B}$ corresponds to the value of the last point of the adsorption isotherm represented in Fig. 2A and may be underestimated. Alternative models may represent better fit of the adsorption isotherms in these conditions, as suggested by Findenegg and coworkers ${ }^{72}$. No buffer effect was observed for BisTris- $\mathrm{HCl}$ and Tris-HCl although a little 
effect was observed for Phosphate for which slightly lower amounts of $\mathrm{HbO}_{2}$ adsorbed in the same $\mathrm{pH}$ conditions.
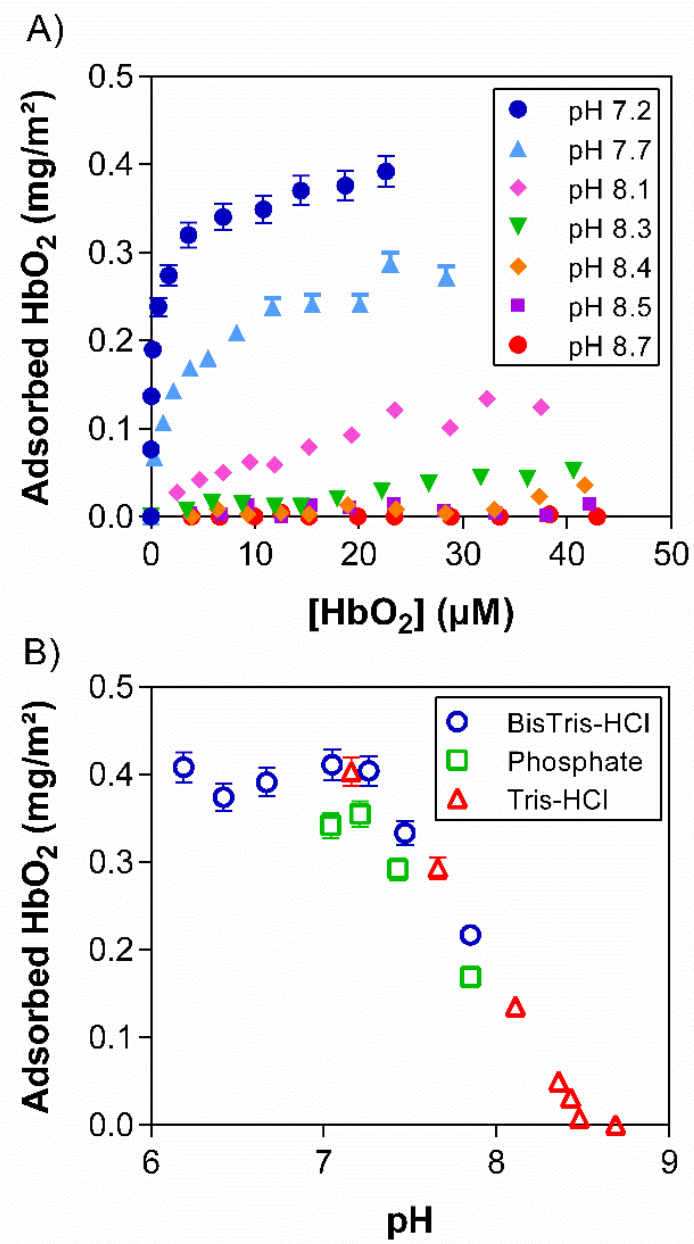

Figure 2. Control of $\mathbf{H b O}_{2}$ adsorption on SNPs by pH. A) Adsorption isotherms of $\mathrm{HbO}_{2}$ on SNPs in $0.1 \mathrm{M}$ Tris- $\mathrm{HCl}$ from $\mathrm{pH} 7.2$ to 8.7 ; B) Maximum amount of adsorbed $\mathrm{HbO}_{2}$ on $\mathrm{SNPs}_{\text {in }}$ 0.1 M BisTris- $\mathrm{HCl}$ (circle), Phosphate (square) and Tris- $\mathrm{HCl}$ (triangle) at different $\mathrm{pH}$. The affinity of $\mathrm{HbO}_{2}$ for SNPs decreases as $\mathrm{pH}$ increases as shown by the decrease of $K_{a d s}$ from $\mathrm{pH} \geq 7$ (Table 1). The adsorption of $\mathrm{HbO}_{2}$ on SNPs is thus favored when the protein is globally positively charged or neutral $(\mathrm{pH} \leq 7.2)$ and becomes less and less favorable with the increase of $\mathrm{HbO}_{2}$ and SNP negative charges $(\mathrm{pH}>7.3)$ until charge repulsion completely prevents protein adsorption $(\mathrm{pH} \geq 8.5)$. Indeed, the electrostatic interactions between the anionic siloxide groups 
and the basic amino acids (Lys, Arg) are known to play a key role in protein adsorption on SNPs ${ }^{69}$ especially when the basic residues form positively charged clusters in the protein structure ${ }^{44,73}$. Hemoglobin $\alpha$ chains and $\beta$ chains contain 14 basic residues (11 Lys, $3 \mathrm{Arg}$ ) and 16 basic residues (11 Lys, $5 \mathrm{Arg}$ ) respectively. It suggests that both subunits could contribute to the electrostatic interactions responsible for $\mathrm{HbO}_{2}$ adsorption and non-adsorption to SNPs. At the same $\mathrm{pH}, K_{a d s}$ is smaller for Phosphate compared to BisTris-HCl or Tris- $\mathrm{HCl}$, suggesting that ion pairing and ion replacement also play a role in $\mathrm{HbO}_{2}$ adsorption on silica.

\begin{tabular}{|l|l|l|l|}
\hline pH & $\begin{array}{l}\text { BisTris- } \\
\text { HCl }\end{array}$ & Phosphate & Tris-HCl \\
\hline 6.4 & $2.110^{6}$ & - & - \\
6.7 & $2.110^{6}$ & - & - \\
7.0 & $2.010^{6}$ & $1.010^{6}$ & - \\
7.3 & $1.710^{6}$ & $0.710^{6}$ & $2.010^{6}$ \\
7.5 & $1.410^{6}$ & $0.410^{6}$ & $0.410^{6}$ \\
7.8 & $0.210^{6}$ & $0.110^{6}$ & - \\
8.1 & - & - & $0.0510^{6}$ \\
\hline
\end{tabular}

Table 1. Adsorption constant $K_{a d s}\left(\mathrm{M}^{-1}\right)$ of $\mathrm{HbO}_{2}$ on SNPs in $0.1 \mathrm{M}$ BisTris-HCl, Phosphate and Tris-HCl.

We can conclude that $\mathrm{HbO}_{2}$ adsorption on SNPs is primarily driven by $\mathrm{pH}$ with a minor effect of the ions in solution. $\mathrm{HbO}_{2}$ adsorption can be fully controlled in a small $\mathrm{pH}$ range, independently of the total protein concentration in solution, from a maximum protein coverage at $\mathrm{pH} 7.3$ to no protein adsorption at $\mathrm{pH} 8.5$.

\subsection{Structural analysis of adsorbed $\mathrm{HbO}_{2}$}

The structure of $\mathrm{HbO}_{2}$ adsorbed on SNPs was investigated by circular dichroism (CD) (Fig. 3) and by UV-visible spectroscopy (Fig. S1) to analyze the protein secondary structure and the oxygenated heme electronic structure respectively. A concentration of $10 \mu \mathrm{M} \mathrm{HbO}_{2}$ and 6.8 $\mathrm{mg} / \mathrm{mL}$ SNPs were chosen to achieve almost complete protein adsorption. The amount of adsorbed $\mathrm{HbO}_{2}$ in this condition is $99 \%$ at $\mathrm{pH} 6.0,90 \%$ at $\mathrm{pH} 7.4$ and $<1 \%$ at $\mathrm{pH} 8.7$ (Table S2). 
The spectra measured at $\mathrm{pH} 6.0$ and at $\mathrm{pH} 7.4$ can thus be attributed to the adsorbed protein with no contribution or little contribution from the free protein in solution at $\mathrm{pH} 6.0$ and at $\mathrm{pH} 7.4$ respectively. As SNPs may interfere with the optical measurement, a control experiment was systematically performed to compare the spectra of free $\mathrm{HbO}_{2}$ with SNPs and native $\mathrm{HbO}_{2}$ without SNPs, both in Tris- $\mathrm{HCl}$ at $\mathrm{pH}$ 8.7. Indeed, no adsorption occurs in this condition so that any change in the protein spectrum would indicate a bias due to the particles in suspension. The $\mathrm{CD}$ spectra of free and native $\mathrm{HbO}_{2}$ measured at $\mathrm{pH} 8.7$ with and without SNPs respectively (Fig. 3C) are identical showing that no protein structure perturbation arises from SNPs in suspension.

The CD spectra of adsorbed $\mathrm{HbO}_{2}$ at $\mathrm{pH} 6.0$ (Fig. 3A) and at pH 7.4 (Fig. 3B) showed a decrease in $|\Delta \varepsilon|$ compared to native $\mathrm{HbO}_{2}$ indicating a modification of the secondary structure after adsorption on SNPs. The spectrum of native $\mathrm{HbO}_{2}$ is characterized by one maximum at $192 \mathrm{~nm}$ and two minima at $208 \mathrm{~nm}$ and $222 \mathrm{~nm}$ corresponding to the predominant $\alpha$-helix secondary structure. As reported before, the secondary structure of $\mathrm{HbO}_{2}$ is identical at $\mathrm{pH} 6.0$, at $\mathrm{pH} 7.4$ and at $\mathrm{pH} 8.7$ in the different buffers ${ }^{60}$. The percentage of $\alpha$-helix calculated from the ellipticity at $222 \mathrm{~nm}^{74}$ decreases from $80 \%$ for native $\mathrm{HbO}_{2}$ to $62 \%$ and $49 \%$ for adsorbed $\mathrm{HbO}_{2}$ at $\mathrm{pH} 7.4$ and at $\mathrm{pH} 6.0$ respectively. The helicity calculated for adsorbed $\mathrm{HbO}_{2}$ at $\mathrm{pH} 7.4$ was corrected from the contribution of free $\mathrm{HbO}_{2}$ in solution.

Spectral deconvolution by $\mathrm{CDNN}^{62}$ confirmed the important loss of $\alpha$-helix structure together with an increase in random coil up to $17 \%$ at $\mathrm{pH} 6.0$. Therefore $\mathrm{HbO}_{2}$ molecule loses a significant part of its helical secondary structure after adsorption on SNPs with a gain of disordered regions, similarly to $\mathrm{HbO}_{2}$ adsorption on quantum dots ${ }^{75}$ and on silver nanoparticles 76. Though the formation of some $\beta$-sheet cannot be excluded, it has also been shown that a 
change in the $\Delta \varepsilon$ ratio at $222 \mathrm{~nm}$ and $208 \mathrm{~nm}$ of $\alpha$-helical proteins can be related to intra- and inter-molecular helix interactions and coiled-coil formation which could be indicative of a modification of adsorbed hemoglobin tertiary structure ${ }^{77}$.
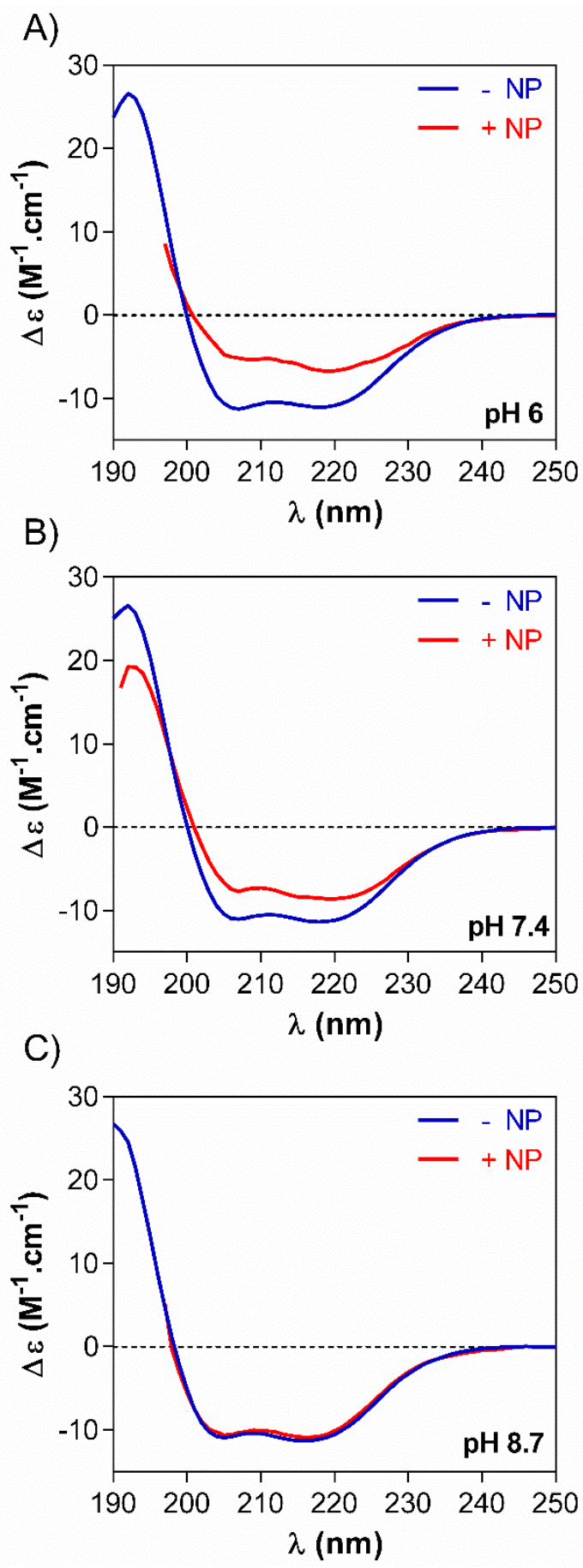
Figure 3. Circular dichroism spectra of adsorbed $\mathbf{H b O}_{2}$ on $\mathbf{S N P s} . \mathrm{HbO}_{2}$ with (red) and without SNPs (blue) in Bis Tris-HCl pH 6.0 (A), Phosphate pH 7.4 (B) and Tris-HCl pH 8.7 (C). The heme group, which is the active site of hemoglobin molecule, is composed of a porphyrin ring with an iron atom at its center allowing oxygen binding. The electronic structure of the heme group was probed by UV-visible spectroscopy. An integrated sphere module was used to collect the light scattered by SNPs allowing the measurement of quality spectra of $\mathrm{HbO}_{2}$ in the 250-700 nm range with SNPs (Fig. S1). As expected, the spectra of $\mathrm{HbO}_{2}$ obtained without SNPs are independent of $\mathrm{pH}$ in the range of protein stability ${ }^{60}$.

In the control spectrum measured at $\mathrm{pH} 8.7$ with SNPs, no shift of the characteristic absorption peaks of $\mathrm{HbO}_{2}$ and no absorption change of the Soret band at $414 \mathrm{~nm}$ and of the Q bands at 541 and $576 \mathrm{~nm}$ that correspond to electronic transitions in the heme group [55] was observed (Fig. $\mathrm{S} 1)$. A slightly higher absorption measured in the $250-400 \mathrm{~nm}$ range in all $\mathrm{pH}$ conditions indicates that light scattering by SNPs is not fully corrected below $400 \mathrm{~nm}$. The spectra of adsorbed $\mathrm{HbO}_{2}$ at $\mathrm{pH} 6.0$ and at $\mathrm{pH} 7.4$ are identical to the spectrum of $\mathrm{HbO}_{2}$ at $\mathrm{pH} 8.7$ indicating that adsorption on SNPs does not lead to any major modification of the heme electronic structure. Despite the large change of oxyhemoglobin secondary structure, the heme group is not altered by adsorption on SNPs.

The activity of hemoglobin does not depend solely on the heme group and is strongly affected by the globin structure and dynamics ${ }^{78}$. The tetrameric structure of hemoglobin is central to the cooperative binding of oxygen ${ }^{79}$. However, the quaternary structure of adsorbed oligomeric proteins remains a blind spot in most cases. We investigated the oxygen binding activity of adsorbed hemoglobin to gain a full picture on the oligomerization state of adsorbed hemoglobin on SNPs. 


\subsection{Functional analysis of adsorbed hemoglobin}

Oxygen binding curves of hemoglobin were measured in BisTris-HCl pH 6.0, Phosphate $\mathrm{pH} 7.4$ and Tris- $\mathrm{HCl} \mathrm{pH} 8.7$ at $25^{\circ} \mathrm{C}$ (Fig. 4). Their sigmoidal shape reflects the cooperative binding of oxygen by tetrameric hemoglobin ${ }^{60}$. The variation in hemoglobin affinity for oxygen with $\mathrm{pH}$ reflects the effect of bound or released protons by hemoglobin on its activity known as the Bohr effect ${ }^{60,80}$. Both effects are quantified by the Hill coefficient $(n)$ and the oxygen partial pressure at half saturation $\left(P_{50}\right)$ determined by fitting the experimental curves with the Hill equation (eq. 3), where $\mathrm{Y}$ is the fraction of oxyhemoglobin and $\mathrm{P}_{\mathrm{O} 2}$ the oxygen partial pressure (Table 2).

$$
\log \frac{Y}{1-Y}=\mathrm{n} \cdot \log P_{O 2}-\log P_{50} \quad \text { (eq. 3) }
$$

No difference between the oxygen binding curves of hemoglobin at $\mathrm{pH} 8.7$ with and without SNPs was observed confirming that SNPs did not interfere with oxygen binding or with the spectroscopic measurement (Fig. 4C). Fig. 4A and Fig. 4B exhibit a more hyperbolic shape of the oxygen binding curves. This significant increase of the affinity of adsorbed hemoglobin follows the decrease in cooperativity as shown by the decrease of $P_{50}$ from $17.1 \pm 0.5$ to $8.7 \pm$ $0.5 \mathrm{mmHg}$ at $\mathrm{pH} 6.0$ and from $7.7 \pm 0.5$ to $4.7 \pm 0.5 \mathrm{mmHg}$ at $\mathrm{pH}$ 7.4. However, adsorbed hemoglobin still experience cooperative binding as evidenced by the Hill coefficients of $1.6 \pm$ 0.1 and $1.9 \pm 0.1$ at $\mathrm{pH} 6.0$ and $\mathrm{pH} 7.4$ respectively. This cooperative behavior cancels the possibility of a dissociation of the tetramer into dimers or monomers during adsorption on SNPs $79,81,82$.

\begin{tabular}{|l|ll|ll|}
\hline pH & \multicolumn{2}{|l|}{$\boldsymbol{P}_{\mathbf{5 0}}$ (mmHg) } & $\boldsymbol{n}$ \\
& $-S N P S$ & + SNPS & - -SNPS & + SNPS \\
\hline pH 6.0 & 17.1 & 8.7 & 2.8 & 1.6 \\
pH 7.4 & 7.7 & 4.7 & 3.0 & 1.9 \\
pH 8.7 & 3.2 & 3.2 & 3.0 & 3.0 \\
\hline
\end{tabular}


Table 2. Oxygen partial pressure at half saturation $\left(P_{50}\right)$ and Hill coefficient $(n)$ of hemoglobin oxygen binding in $0.1 \mathrm{M}$ BisTris- $\mathrm{HCl} \mathrm{pH}$ 6.0, Phosphate $\mathrm{pH} 7.4$ and Tris- $\mathrm{HCl} \mathrm{pH}$ 8.7 at $25^{\circ} \mathrm{C}$ with and without SNPs. Values are given with an uncertainty of $\pm 0.5 \mathrm{mmHg}\left(\mathrm{P}_{50}\right)$ and $\pm 0.1(\mathrm{n})$. 


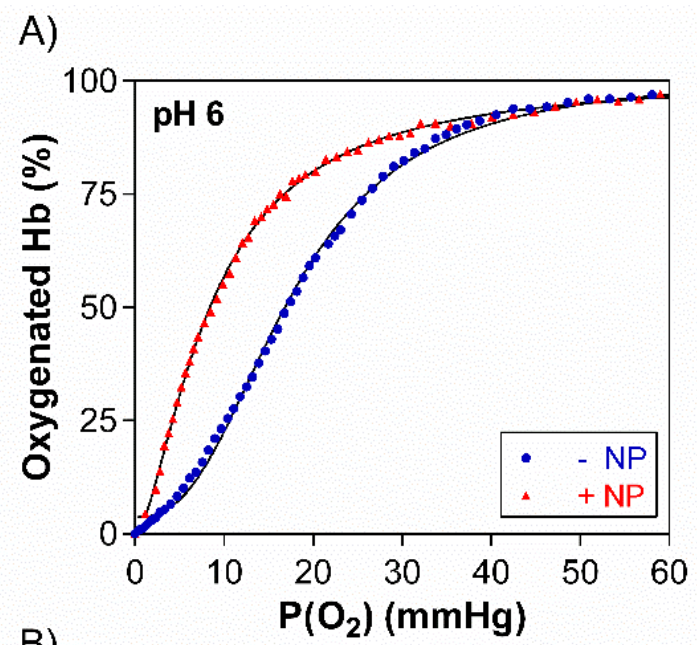

B)

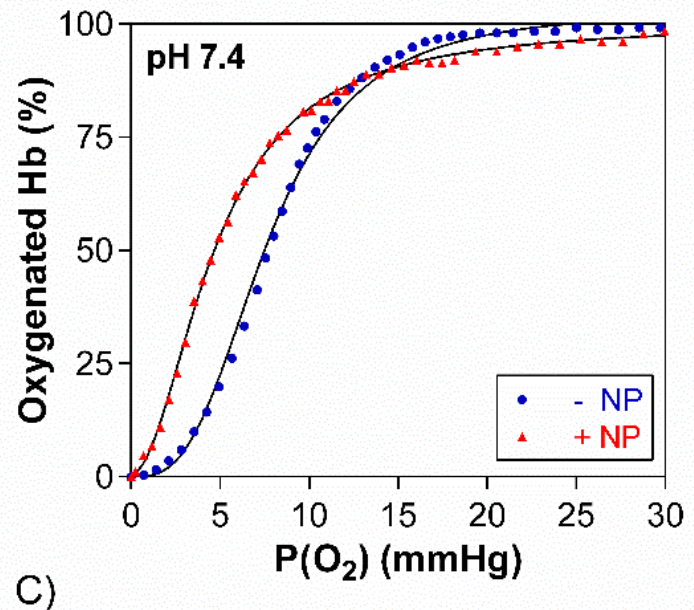

C)

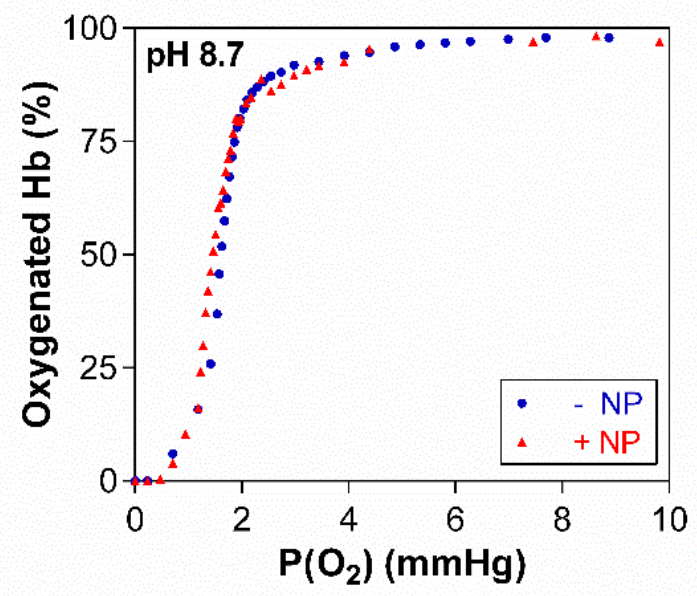

Figure 4. Effect of SNPs on hemoglobin activity. Oxygen binding curves of hemoglobin with (red) and without (blue) SNPs in BisTris- $\mathrm{HCl}$ pH 6.0 (A), Phosphate $\mathrm{pH} 7.4$ (B) and Tris-HCl pH 8.7 (C). Black line represents fitting by the Hill equation. 
We also investigated the effect of temperature on the activity of adsorbed hemoglobin on SNPs. The oxygen binding curves measured at $37^{\circ} \mathrm{C}$ at pH 6 and at $\mathrm{pH} 7.4$ (Fig. S2) show a clear increase in oxygen affinity and decrease in cooperativity due to hemoglobin adsorption on SNPs in addition to the sole effect of temperature on hemoglobin activity (Table S3). Therefore, all the features observed at $25^{\circ} \mathrm{C}$ after adsorption on SNPs are preserved at $37^{\circ} \mathrm{C}$ in physiological conditions.

\subsection{Binding of heterotropic effectors to adsorbed hemoglobin}

Heterotropic effectors such as inositol hexaphosphate (IHP) and 2,3-diphosphoglycerate (DPG) have well-defined binding sites in the tetrameric protein. DPG is a natural effector of hemoglobin present in red blood cells at a concentration of $6 \mathrm{mM}$. It binds to hemoglobin, decreases hemoglobin oxygen affinity and eases oxygen release in tissues. Since adsorption of hemoglobin on SNPs increases hemoglobin affinity, we tested whether this effect could be counterbalanced by the addition of DPG. A second effector, IHP, which has the same binding site as DPG ${ }^{83}$ induces a larger decrease of hemoglobin affinity was also tested. DPG and IHP are both composed of negatively charged inorganic phosphate groups. The oxygen binding curves of adsorbed hemoglobin were measured with DPG or IHP in BisTris-HCl pH 6.0 (Fig. 5). The effector was added either before or after hemoglobin adsorption on SNPs to probe the accessibility and the structural integrity of the effector binding site after adsorption. The affinity of native hemoglobin significantly decreased after addition of DPG or IHP with an increase of $P_{50}$ by a factor 2 after addition of DPG $(38.5 \pm 0.5 \mathrm{mmHg})$ and by a factor 6 after addition of IHP $(110 \pm 1 \mathrm{mmHg})$. Hemoglobin cooperativity was maintained after binding of DPG $(n=2.8 \pm 0.1)$ but decreased after binding of IHP $(n=2.2 \pm 0.1)$. We checked that there was no $\mathrm{pH}$ change after addition of an excess of DPG or IHP to the buffered solutions. 
A)
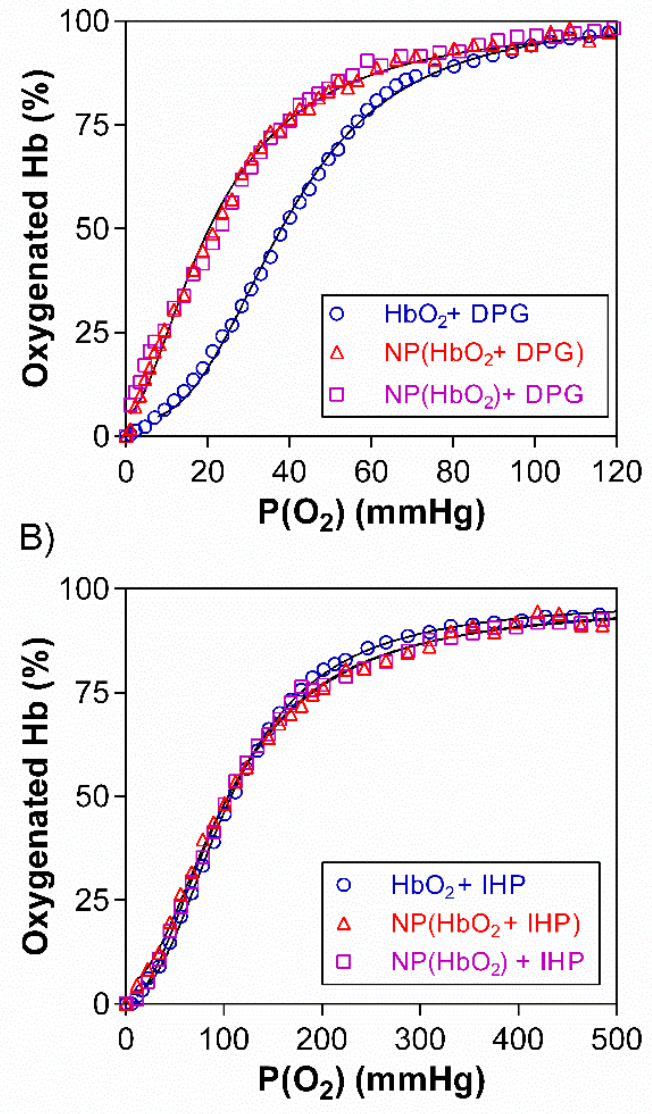

Figure 5. Effect of DPG and IHP effectors on adsorbed hemoglobin activity. Oxygen

binding curves of native hemoglobin (circle) and adsorbed hemoglobin (triangle and square) with DPG (A) or with IHP (B) in $0.1 \mathrm{M}$ BisTris-HCl pH 6.0 at $25^{\circ} \mathrm{C}$. DPG or IHP were added either before (triangle) or after (square) adsorption of $\mathrm{HbO}_{2}$ on silica NPs. Fitting by Hill equation is represented by a black line. Hemoglobin concentration is $50 \mu \mathrm{M}$, SNP concentration is 34 $\mathrm{mg} / \mathrm{mL}, \mathrm{DPG}$ and IHP concentration is $125 \mu \mathrm{M}$.

The affinity of adsorbed hemoglobin significantly decreased after addition of DPG $(22.0 \pm 0.5$ $\mathrm{mmHg})$ or IHP $(104 \pm 1 \mathrm{mmHg})$ compared to adsorbed hemoglobin without effectors $(8.7 \pm 0.5$ $\mathrm{mmHg}$ ). It shows that both effectors can efficiently shift adsorbed hemoglobin affinity towards lower values (Table 3). Interestingly, the oxygen binding curve of adsorbed hemoglobin with IHP is identical to the one of native hemoglobin with IHP (Fig. 5B), whereas the oxygen binding 
curve of adsorbed hemoglobin with DPG exhibits the characteristic higher affinity and lower cooperativity compared to native hemoglobin with DPG (Fig. 5A) as observed previously without effectors. No release of adsorbed hemoglobin was observed after addition of DPG or IHP. Therefore we can conclude that both effectors efficiently bind to adsorbed hemoglobin and modulate its activity. In the case of IHP, its effect is predominant over the effect of adsorption to SNPs: the functional signature of the adsorbed protein is completely cancelled by the addition of the effector. On the contrary, in the case of DPG, the activity of adsorbed hemoglobin results from a combination of the effects of adsorption and effector binding.

\begin{tabular}{|l|ll|ll|}
\hline \multirow{2}{*}{ Effector } & \multicolumn{2}{|l|}{$\boldsymbol{P}_{50}(\mathbf{m m H g})$} & $\boldsymbol{n}$ & \\
\hline DPG & 38.5 & $\begin{array}{l}22.0^{(\mathrm{a})} \\
23.0^{(\mathrm{b})}\end{array}$ & -2.8 & 1.7 \\
\hline IHP & 110 & $\begin{array}{l}104^{(\mathrm{a})} \\
104^{(\mathrm{b})}\end{array}$ & 2.2 & 2.1 \\
\hline
\end{tabular}

Table 3. Oxygen partial pressure at half saturation ( $\left.P_{50}\right)$ and Hill coefficient (n) of free and adsorbed hemoglobin with DPG or IHP effectors in $0.1 \mathrm{M}$ BisTris- $\mathrm{HCl} \mathrm{pH} 6.0$ at $25^{\circ} \mathrm{C}$. DPG or IHP were added either before (a) or after (b) hemoglobin adsorption on SNPs. Values are given with an uncertainty of $0.5 \mathrm{mmHg}\left(P_{50}, \mathrm{DPG}\right), 1 \mathrm{mmHg}\left(P_{50}, \mathrm{IHP}\right)$ and $0.1(n)$.

The oxygen binding curves of adsorbed hemoglobin are identical whether the effector was added before or after adsorption on SNPs. It clearly indicates that (i) DPG and IHP binding site is preserved and accessible after protein adsorption, and (ii) binding of the effector does not prevent adsorption on SNPs.

These results highlight the possibility of tuning hemoglobin activity to lower or higher affinity at will via a combination of $\mathrm{pH}$ and temperature values, binding of heterotropic effectors as DPG or IHP and adsorption on SNPs. From this point of view, silica nanoparticles may be considered as 
a novel positive heterotropic effector of hemoglobin leading to a specific structural and functional state.

\subsection{Reversibility of the structural and functional modifications of absorbed $\mathrm{HbO}_{2}$}

Desorption of $\mathrm{HbO}_{2}$ from SNPs was tested in different conditions starting from adsorbed $\mathrm{HbO}_{2}$ in BisTris- $\mathrm{HCl}$ pH 6.0 or in Phosphate $\mathrm{pH} 7.4$ (Table S4). The SNPs were centrifuged and resuspended in a new solution. No desorption was observed in water, $\mathrm{NaCl} 1 \mathrm{M}, \mathrm{CaCl}_{2} 1 \mathrm{M}$, BisTris- $\mathrm{HCl} \mathrm{pH} 6.0$ or Phosphate $\mathrm{pH}$ 7.4. It means that $\mathrm{HbO}_{2}$ cannot be desorbed by dilution, ion exchange or washing. On the contrary, almost complete desorption was observed in Tris- $\mathrm{HCl}$ at $\mathrm{pH} 8.7$ after $1 \mathrm{~h}$ mixing or in softer conditions by dialysis overnight, with up to $90 \%$ of the adsorbed protein released in the solution. This result confirms the key role of electrostatic interactions in $\mathrm{HbO}_{2}$ adsorption on SNPs and it provides a useful tool to study the reversibility of the structural and functional modifications of adsorbed $\mathrm{HbO}_{2}$.

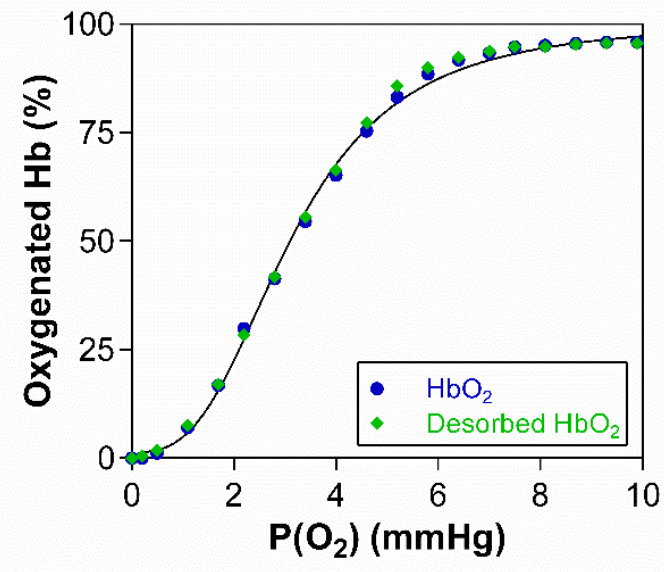

Figure 6. Functional analysis of desorbed hemoglobin. Oxygen binding curves of native (circle) and desorbed (diamond) hemoglobin in $0.1 \mathrm{M}$ Tris- $\mathrm{HCl} \mathrm{pH}$ 8.7. Fitting by Hill equation is represented by a black line.

We analyzed the structure and the function of $\mathrm{HbO}_{2}$ desorbed from SNPs by dialysis in $0.01 \mathrm{M}$ Tris- $\mathrm{HCl} \mathrm{pH}$ 8.7. The UV-vis and $\mathrm{CD}$ spectra of desorbed $\mathrm{HbO}_{2}$ are almost identical to the 
spectra of native $\mathrm{HbO}_{2}$ (Fig. S3) indicating almost full reversibility of the structural modifications after desorption. The slight difference observed in CD spectra may indicate some remaining secondary and/or tertiary structural modifications ${ }^{77,84}$.

The analysis of the oxygen binding curves of desorbed hemoglobin (Fig. 6) confirmed that desorbed hemoglobin regained its native activity. Thus oxyhemoglobin can switch from one structural and functional state to another following an adsorption/desorption cycle in a reversible manner. This result indicates that adsorption of $\mathrm{HbO}_{2}$ on SNPs represents a highly tunable system in which the adsorption/desorption of the protein can be fully controlled by simple $\mathrm{pH}$ change.

\section{Discussion}

\section{Molecular mechanisms of $\mathrm{HbO}_{2}$ adsorption on SNPs}

Electrostatic interactions play a key role in $\mathrm{HbO}_{2}$ adsorption on SNPs as evidenced by the control of adsorption and the adsorption/desorption cycle as a function of $\mathrm{pH}$. This is in agreement with the previous observation by Kondo et al of hemoglobin adsorption on ultrafine silica particles ${ }^{85}$. The electrostatic interactions between the basic residues and the siloxide groups can counterbalance the loss of H-bonding due to the large loss of the secondary structure in the enthalpic budget ${ }^{47}$. However, other interactions can possibly contribute to $\mathrm{HbO}_{2}$ adsorption such as polar interactions and H-bond formation ${ }^{43}$. In particular, H-bonds between silanol groups and the imidazole ring of His residue are known to favor peptide interaction with silica and to participate in silica biomineralisation in vivo ${ }^{86}$. The molecular mechanisms of protein adsorption on the same silica NPs were identified in our previous study on a larger protein population ${ }^{44}$. The structural determinants are the electrostatic interactions between clusters of basic residues (in particular Arg) and the silanol groups on one hand, and protein 
flexibility associated to a low content of aromatic residues and $\pi$ - $\pi$ interactions on the other hand. Moreover, clusters of basic residues have also been identified in the binding sites of myoglobin on silica NPs, a hemoprotein which has a similar primary and secondary structure as hemoglobin. ${ }^{47}$

Desorption of $\mathrm{HbO}_{2}$ at $\mathrm{pH} 8.7$ is likely due to electrostatic repulsion which can result from the deprotonation of silanol groups on the silica surface (surface charging), and/or from the deprotonation of Arg and Lys residues (loss of positive charges) (Fig. 7). Even though the $\mathrm{pK}_{\mathrm{a}}$ of the side chain of the free basic amino acid is 12.0 and 10.4 respectively, it can widely vary inside the protein structure suggesting that some residues may already be deprotonated at $\mathrm{pH} 8.7^{87,88}$. The hydration layer plays an important role in the adsorption of biomolecules on inorganic surfaces. From an energetic point of view, the displacement of water molecules from the silica surface can contribute to the adsorption of proteins on SNPs by the entropic gain associated to the release of water molecules from the surface ${ }^{47}$. Water structure at the silica surface depends on the protonation state of the silanol groups. The orientation of water molecules, e.g. pointing towards the silica surface or towards the bulk, follows the formation of H-bonds either with the oxygen atom of the charged $\mathrm{Si}^{-} \mathrm{O}^{-}$groups, or with the oxygen or hydrogen atoms of the neutral Si-OH group ${ }^{89}$. A large number of deprotonated charged groups at higher $\mathrm{pH}$ also creates an electric field that contributes to water molecule orientation by charge-dipole interaction in the electric double layer. Thus, the surface properties to consider to describe protein adsorption on SNPs at a molecular level include the structure and protonation state of the silanol groups, the water structure and H-bond network at the interface and the effect of ions on the surface charge density ${ }^{47,70,90}$. A description at a molecular level of the interactions between proteins and nanoparticles could help to further rationalize and control protein adsorption. 
Interestingly, adsorbed hemoglobin is still responsive to the Bohr effect in a similar extent as native hemoglobin with a $P_{50}$ divided by two from $\mathrm{pH} 6.0$ to $\mathrm{pH} 7.4$. It indicates that the proton binding sites involved in this $\mathrm{pH}$ range are not affected by the adsorption on SNPs. However, their position in hemoglobin structure is not well defined because of the large number of possible residues. For example, hemoglobin tetramer counts 38 histidine residues which all have various $\mathrm{pK}_{\mathrm{a}}$ depending on their local environment and the protonation state of the other residues ${ }^{91}$.

\section{Reorganization of the secondary structure of the adsorbed protein}

The significant loss of the helical structure means that the H-bond network that holds the protein secondary structure is destabilized during adsorption on SNPs. The difference in structural modification at $\mathrm{pH} 6.0$ and at $\mathrm{pH} 7.4$ is likely due to the lower affinity of $\mathrm{HbO}_{2}$ for the silica surface at $\mathrm{pH} 7.4$ where the molecular interactions, in particular the electrostatic interactions between basic amino acids and siloxide groups, may be fewer and/or weaker, resulting in less constraints on the adsorbed protein structure.

$\mathrm{CD}$ analysis does not allow to identify the protein domains affected by the loss of secondary structure and to decipher between a short-range effect due to the direct interaction between one or several residues involved in an $\alpha$-helix and the SNPs surface; and/or a long-range effect ${ }^{91}$ whereby $\alpha$-helices which are not in close contact with the surface could be destabilized due to the global reorganization of the protein structure after adsorption. Indeed, if $\mathrm{HbO}_{2}$ is 'anchored' on the silica surface through strong electrostatic interactions between basic residues and negatively charged moieties, then mechanical stress could apply to domains that are not in direct contact with the surface. Moreover, the extent of the conformational changes of adsorbed hemoglobin increases with time ${ }^{92}$ which suggests further structural reorganization of the adsorbed protein on the surface following the first interaction and binding step. Such nonlocal 
effects would imply that the disordered regions of the proteins would not necessarily correspond to the sole protein binding sites on SNPs.

\section{Oligomeric state of adsorbed hemoglobin}

The binding site of DPG and IHP is in the cavity formed by the two $\beta$ chains of deoxyhemoglobin and involves the interactions of the side chains of the residues Val1, His2, Lys82 and His 143 with the negative charges of the phosphate groups of the effectors ${ }^{93-95}$. Therefore, the binding of DPG or IHP to adsorbed hemoglobin evidenced by the decrease of the oxygen affinity confirms the tetrameric structure of adsorbed hemoglobin. Indeed, if binding of

DPG or IHP to a hemoglobin dimer may be possible, the decrease in affinity is much lower ${ }^{96}$. It also indicates that the cavity between $\beta$ chains is fully accessible to small molecules after adsorption. Our conclusion differs from the study of Hallaway and coworkers who concluded that the increase of hemoglobin affinity after adsorption on a Cab-O-Sil surface was due to the dissociation into dimers ${ }^{97}$.

The distinct effect of DPG and IHP on adsorbed hemoglobin activity remains an open question. The activity of the adsorbed protein is identical to the activity of native hemoglobin when IHP is bound. Moreover, the cooperativity of adsorbed hemoglobin bound to IHP $(n=2.1 \pm 0.1)$ is higher than the cooperativity of adsorbed hemoglobin without effector $(n=1.6 \pm 0.1)$. We checked the secondary structure of adsorbed $\mathrm{HbO}_{2}$ in presence of IHP by circular dichroism. The CD spectra of adsorbed $\mathrm{HbO}_{2}$ are identical with and without IHP (Fig. S4) with an important loss of the helical structure after adsorption on SNPs. Thus, when adsorbed $\mathrm{HbO}_{2}$ binds IHP, it retains a native activity despite the partial loss of its secondary structure.

\section{Relationship between structural and functional modifications of adsorbed $\mathrm{HbO}_{2}$}


Contrary to denatured proteins, the significant loss of $\mathrm{HbO}_{2}$ secondary structure does not induce a decrease of its activity but a large increase in oxygen binding affinity. Our results demonstrate that this effect can be rationalized by the preservation of the heme group and of the tetrameric structure of adsorbed $\mathrm{HbO}_{2}$ with heme-heme interactions (Fig. 7). We can also notice that the loss of secondary structure is lesser than observed for heat or acidic denaturation of $\mathrm{HbO}_{2}{ }^{98}$. Whereas the monomer of absorbed myoglobin has two binding sites for silica ${ }^{73}$, the lack of structural information at a residue level on tetramer structure of adsorbed hemoglobin or on binding sites prevents deeper analysis. Yet the increase of adsorbed $\mathrm{HbO}_{2}$ activity and the full reversibility of the structural and functional modifications suggest that the structural state of adsorbed hemoglobin is different from a denatured state. We previously investigated the dynamics of myoglobin on SNPs and showed that, contrary to Norde's prediction, adsorption of myoglobin on SNPs resulted in a decrease in protein dynamics ${ }^{47}$. This result suggests that a decrease in hemoglobin dynamics could also impact its oxygen binding activity.

Native $\mathrm{Hb}$

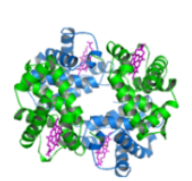

Adsorbed $\mathrm{Hb}$

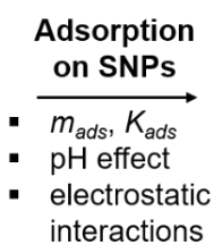

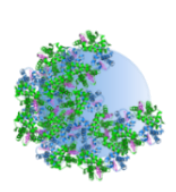

\section{Desorbed $\mathrm{Hb}$}

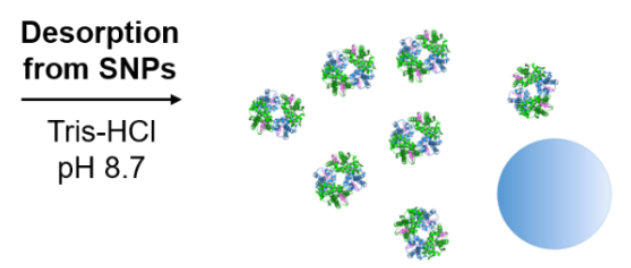

Functional properties Structural properties

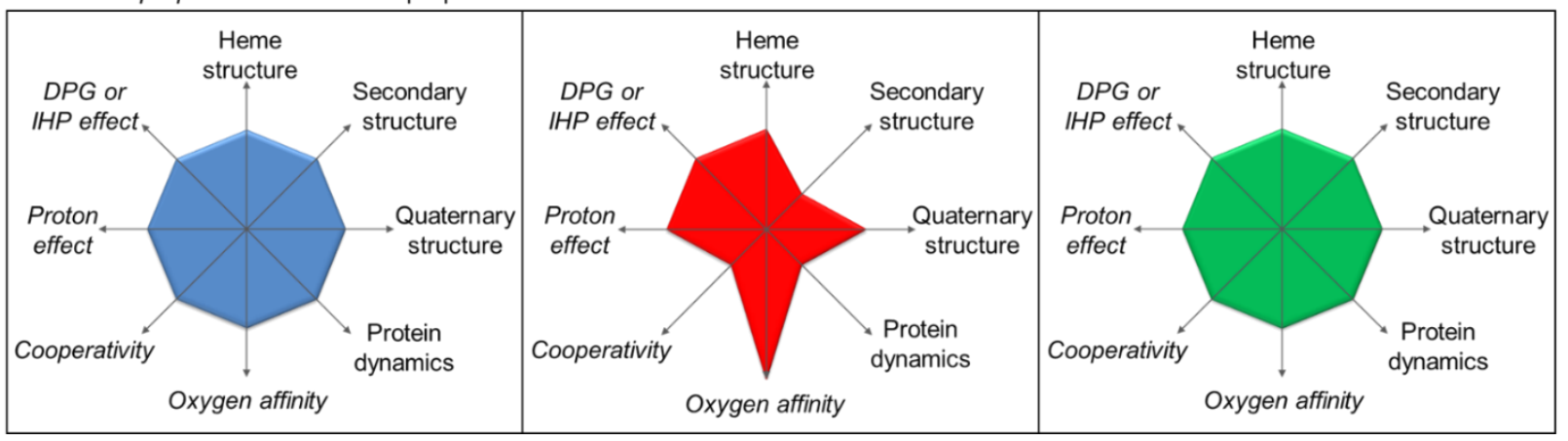

Figure 7. Relationship between the adsorption mechanism on SNPs and the structural,

functional and dynamic properties of hemoglobin. The value attributed to each criteria 
indicates an increase, a decrease or a preservation of a structural or functional property compared to native hemoglobin. The decrease in adsorbed hemoglobin dynamics is based on the experimental results showing a decrease of myoglobin dynamics after adsorption on the SNPs ${ }^{47}$. Numerous models have been proposed to account for hemoglobin cooperativity, such as the allosteric model proposed by Monod, Wyman and Changeux ${ }^{99}$, the stereochemical model suggested by Perutz ${ }^{100}$ or the dynamic allosteric model submitted by Yonetani ${ }^{78}$ to cite only a few of them. Though the aim of this study is not to test the different models, we can discuss our experimental results on adsorbed hemoglobin structure/function/dynamics in line with the main models proposed.

In the sequential model of cooperativity based on Perutz hypothesis of two distinct quaternary structures of hemoglobin, the cooperative oxygen binding is explained by a switch from a low affinity form to a high affinity form ${ }^{100}$. We have demonstrated that hemoglobin tetrameric structure was preserved after adsorption on SNPs. Though further structural analysis would be necessary, our results do not support the idea that different quaternary structures are present and could afford for the increase in affinity of absorbed hemoglobin after a sequential mechanism (as that proposed by Perutz) given the large structure loss observed after adsorption. According to Yonetani, thermic fluctuations of hemoglobin ease or prevent oxygen release from the heme through the globin, a higher dynamic resulting in a lower affinity of hemoglobin ${ }^{78,101}$. If we assume a decrease of adsorbed hemoglobin dynamics as suggested from the analysis of myoglobin dynamics ${ }^{47}$, then this model could possibly account for the increase in oxygen affinity.

Finally, the tunable adsorption and desorption of hemoglobin on SNPs with $\mathrm{pH}$ change, and the full control of hemoglobin activity by $\mathrm{pH}$, temperature and the addition of inorganic phosphate 
effectors opens the way to an interesting system whereby protein adsorption on nanoparticles can allow for full control over hemoglobin oxygen binding activity.

\section{Conclusion}

We investigated porcine hemoglobin adsorption on silica nanoparticles and we analyzed the structural and functional modifications of the adsorbed protein. $\mathrm{HbO}_{2}$ adsorption can be controlled by $\mathrm{pH}$ from maximum adsorption between $\mathrm{pH} 6.0$ and 7.0 to no adsorption at $\mathrm{pH} 8.5$. The structural analysis of adsorbed $\mathrm{HbO}_{2}$ on SNPs revealed a significant loss of secondary structure and a preservation of the heme oxidation state and environment. Despite the large secondary structure loss, adsorbed hemoglobin exhibited enhanced activity with a higher oxygen affinity and a lower cooperativity. The affinity of adsorbed hemoglobin could be further controlled by $\mathrm{pH}$, temperature and the addition of inorganic phosphate effectors. The oxygen binding properties of adsorbed hemoglobin and its capacity to efficiently bind DPG and IHP effectors indicate that adsorbed hemoglobin retained its tetrameric structure. Moreover, the structural and functional modifications of adsorbed hemoglobin are fully reversible after complete desorption at $\mathrm{pH} 8.7$.

Our results suggest that adsorption leads to a new state characterized by specific structural, functional and dynamic features with full reversibility in a way that significantly differs from protein denaturation. Finally, silica nanoparticles may be considered as a new and alternative positive effector for hemoglobin.

\section{ASSOCIATED CONTENT}

Zeta potential of SNPs; UV-visible spectra of $\mathrm{HbO}_{2}$; oxygen binding curves at $37^{\circ} \mathrm{C}$; structural analysis of desorbed $\mathrm{HbO}_{2}$; structural analysis of $\mathrm{HbO}_{2}$ bound to IHP.

\section{AUTHOR INFORMATION}




\section{Corresponding Author}

* Email: stephanie.devineau@cbni.ucd.ie

\section{Present Address}

${ }^{\#}$ Centre for BioNano Interactions, School of Chemistry, University College Dublin, Belfield,

Dublin 4, Ireland

\section{Funding sources}

The authors acknowledge support from the Programme Transversal de Toxicologie of CEA.

\section{ABBREVIATIONS}

SNP: silica nanoparticle; NM: nanomaterial; $\mathrm{HbO}_{2}$ : oxyhemoglobin; DPG: 2,3-

diphosphoglycerate; IHP: inositol hexaphosphate.

\section{REFERENCES}

(1) Delgado, G. C. Economics and Governance of Nanomaterials: Potential and Risks. Technol. Soc. 2010, 32 (2), 137-144.

(2) Hendren, C. O.; Mesnard, X.; Droge, J.; Wiesner, M. R. Estimating Production Data for Five Engineered Nanomaterials as a Basis for Exposure Assessment. Environ. Sci. Technol. 2011, 45 (7), 2562-2569.

(3) Piccinno, F.; Gottschalk, F.; Seeger, S.; Nowack, B. Industrial Production Quantities and Uses of Ten Engineered Nanomaterials in Europe and the World. J. Nanoparticle Res. 2012, 14 (9).

(4) Kagan, C. R.; Fernandez, L. E.; Gogotsi, Y.; Hammond, P. T.; Hersam, M. C.; Nel, A. E.; Penner, R. M.; Willson, C. G.; Weiss, P. S. Nano Day: Celebrating the Next Decade of Nanoscience and Nanotechnology. ACS Nano 2016, in press.

(5) Cao, G. Nanostructures \& Nanomaterials. Synthesis, Properties and Applications; 2004.

(6) Aitken, R. J.; Chaudhry, M. Q.; Boxall, A. B. A.; Hull, M. Manufacture and Use of Nanomaterials: Current Status in the UK and Global Trends. Occup. Med. (Chic. Ill). 2006, 56 (5), 300-306.

(7) Murty, B. S.; Shankar, P.; Raj, B.; Rath, B. B.; Murday, J. Textbook of Nanoscience and Nanotechnology; Springer, 2011.

(8) Castner, D. G.; Ratner, B. D. Biomedical Surface Science: Foundations to Frontiers. Surf. Sci. 2002, $500(1-3), 28-60$.

(9) Kasemo, B. Biological Surface Science. Surf. Sci. 2002, 500, 656-677.

(10) Salata, O. V. Applications of Nanoparticles in Biology and Medicine. J. Nanobiotechnology 2004, $6(3), 1-6$.

(11) Ferrari, M. Cancer Nanotechnology: Opportunities and Challenges. Nat. Rev. Cancer 2005, 5 (3), 161-171.

(12) Sanhai, W. R.; Sakamoto, J. H.; Canady, R.; Ferrari, M. Seven Challenges for Nanomedicine. Nat. Nanotechnol. 2008, 3 (5), 242-244.

(13) Regnier, M.; Metz, B.; Tilstra, W.; Hendriksen, C.; Jiskoot, W.; Norde, W.; Kersten, G. Structural Perturbation of Diphtheria Toxoid upon Adsorption to Aluminium Hydroxide Adjuvant. Vaccine 2012, 30 (48), 6783-6788. 
(14) OECD. Nanomaterials in Waste Streams. Current Knowledge on Risks and Impacts; OECD Publishing: Paris, 2016.

(15) Vance, M. E.; Kuiken, T.; Vejerano, E. P.; McGinnis, S. P.; Hochella, M. F.; Hull, D. R. Nanotechnology in the Real World: Redeveloping the Nanomaterial Consumer Products Inventory. Beilstein J. Nanotechnol. 2015, 6 (1), 1769-1780.

(16) Nel, A.; Xia, T.; Mädler, L.; Li, N. Toxic Potential of Materials at the Nanolevel. Science 2006, 311 (February 2006), 622-627.

(17) Buzea, C.; Pacheco, I. I.; Robbie, K. Nanomaterials and Nanoparticles: Sources and Toxicity. Biointerphases 2007, 2 (4), MR17-71.

(18) Linkov, I.; Steevens, J. Nato Science for Peace and Security Series - C: Environmental Security. Nanomaterials: Risks and Benefits, Ed. Spring.; 2009.

(19) Gil, P. R.; Elder, A.; Parak, W. J. Correlating Physico-Chemical with Toxicological Properties of Nanoparticles: The Present and the Future. 2010, 4 (10), 5527-5531.

(20) Keller, A. A.; McFerran, S.; Lazareva, A.; Suh, S. Global Life Cycle Releases of Engineered Nanomaterials. J. Nanoparticle Res. 2013, 15 (6), 1-16.

(21) Gunsolus, I. L.; Haynes, C. L. Analytical Aspects of Nanotoxicology. Anal. Chem. 2016, 88 (1), 451-479.

(22) Bettini, S.; Boutet-robinet, E.; Cartier, C.; Coméra, C.; Gaultier, E.; Dupuy, J.; Naud, N.; Taché, S.; Grysan, P.; Reguer, S.; et al. Food-Grade TiO 2 Impairs Intestinal and Systemic Immune Homeostasis, Initiates Preneoplastic Lesions and Promotes Aberrant Crypt Development in the Rat Colon. Sci. Rep. 2017, 7, 1-13.

(23) Nel, A. E.; Mädler, L.; Velegol, D.; Xia, T.; Hoek, E. M. V; Somasundaran, P.; Klaessig, F.; Castranova, V.; Thompson, M. Understanding Biophysicochemical Interactions at the Nano-Bio Interface. Nat. Mater. 2009, 8 (7), 543-557.

(24) Lundqvist, M.; Stigler, J.; Elia, G.; Lynch, I.; Cedervall, T.; Dawson, K. A. Nanoparticle Size and Surface Properties Determine the Protein Corona with Possible Implications for Biological Impacts. Proc. Natl. Acad. Sci. U. S. A. 2008, 105 (38), 14265-14270.

(25) Lynch, I.; Cedervall, T.; Lundqvist, M.; Cabaleiro-Lago, C.; Linse, S.; Dawson, K. A. The Nanoparticle-Protein Complex as a Biological Entity; a Complex Fluids and Surface Science Challenge for the 21st Century. Adv. Colloid Interface Sci. 2007, 134-135, 167-174.

(26) Monopoli, M. P.; Walczyk, D.; Campbell, A.; Elia, G.; Lynch, I.; Baldelli Bombelli, F.; Dawson, K. A. Physical-Chemical Aspects of Protein Corona: Relevance to in Vitro and in Vivo Biological Impacts of Nanoparticles. J. Am. Chem. Soc. 2011, 133 (8), 2525-2534.

(27) Lynch, I.; Salvati, A.; Dawson, K. A. What Does the Cell See? Nat. Nanotechnol. 2009, 4 (9), 546547.

(28) Monopoli, M. P.; Åberg, C.; Salvati, A.; Dawson, K. A. Biomolecular Coronas Provide the Biological Identity of Nanosized Materials. Nat. Nanotechnol. 2012, 7 (12), 779-786.

(29) Shaw, C. A.; Mortimer, G. M.; Deng, Z. J.; Carter, E. S.; Connell, S. P.; Miller, M. R.; Duffin, R.; Newby, D. E.; Hadoke, P. W. F.; Minchin, R. F. Protein Corona Formation in Bronchoalveolar Fluid Enhances Diesel Exhaust Nanoparticle Uptake and pro-Inflammatory Responses in Macrophages. Nanotoxicology 2016, 5390 (April), 1-11.

(30) Guadagnini, R.; Halamoda Kenzaoui, B.; Walker, L.; Pojana, G.; Magdolenova, Z.; Bilanicova, D.; Saunders, M.; Juillerat-Jeanneret, L.; Marcomini, A.; Huk, A.; et al. Toxicity Screenings of Nanomaterials: Challenges due to Interference with Assay Processes and Components of Classic in Vitro Tests. Nanotoxicology 2015, 9 (Oecd 2010), 13-24.

(31) Caracciolo, G.; Palchetti, S.; Colapicchioni, V.; Digiacomo, L.; Pozzi, D.; Capriotti, A. L.; La Barbera, G.; Lagana, A. Stealth Effect of Biomolecular Corona on Nanoparticle Uptake by Immune Cells. Langmuir 2015, 31 (39), 10764-10773.

(32) Landgraf, L.; Christner, C.; Storck, W.; Schick, I.; Krumbein, I.; Dahring, H.; Haedicke, K.; HeinzHerrmann, K.; Teichgraber, U.; Reichenbach, J. R.; et al. A Plasma Protein Corona Enhances the Biocompatibility of Au@Fe3O4 Janus Particles. Biomaterials 2015, 68, 77-88. 
(33) Butcher, N. J.; Mortimer, G. M.; Minchin, R. F. Unravelling the Stealth Effect. Nat. Nanotechnol. 2016, 11, 310-311.

(34) Vroman, L. When Blood Is Touched. Materials (Basel). 2009, 2 (4), 1547-1557.

(35) Aggarwal, P.; Hall, J. B.; McLeland, C. B.; Dobrovolskaia, M. A.; McNeil, S. E. Nanoparticle Interaction with Plasma Proteins as It Relates to Particle Biodistribution, Biocompatibility and Therapeutic Efficacy. Adv. Drug Deliv. Rev. 2009, 61 (6), 428-437.

(36) Zoungrana, T.; Findenegg, G.; Norde, W. Structure, Stability, and Activity of Adsorbed Enzymes. J. Colloid Interface Sci. 1997, 190 (2), 437-448.

(37) Norde, W.; Favier, J. P. Structure of Adsorbed and Desorbed Proteins. Colloids and Surfaces 1992, 64, 87-93.

(38) Lundqvist, M.; Sethson, I.; Jonsson, B. H. Protein Adsorption onto Silica Nanoparticles: Conformational Changes Depend on the Particles' Curvature and the Protein Stability. Langmuir 2004, 20 (24), 10639-10647.

(39) Sanfins, E.; Dairou, J.; Hussain, S.; Busi, F.; Chaffotte, A. F.; Rodrigues-Lima, F.; Dupret, J. M. Carbon Black Nanoparticles Impair Acetylation of Aromatic Amine Carcinogens through Inactivation of Arylamine N -Acetyltransferase Enzymes. ACS Nano 2011, 5 (6), 4504-4511.

(40) Lu, M.; Zhao, C.; Wang, Q.; You, G.; Wang, Y.; Deng, H.; Chen, G.; Xia, S.; Zhao, J.; Wang, B.; et al. Preparation, Characterization and in Vivo Investigation of Blood-Compatible HemoglobinLoaded Nanoparticles as Oxygen Carriers. Colloids Surfaces B Biointerfaces 2016, 139, 171-179.

(41) Norde, W.; Anusiem, C. I. Adsorption, Desorption and Re-Adsorption of Proteins on Solid Surfaces. Colloids And Surfaces 1992, 66 (I 992), 73-80.

(42) Norde, W. My Voyage of Discovery to Proteins in Flatland ....and beyond. Colloids Surfaces B Biointerfaces 2008, 61 (1), 1-9.

(43) Czeslik, C. Factors Ruling Protein Adsorption. Zeitschrift für Phys. Chemie 2004, 218 (7-2004), 771-801.

(44) Mathé, C.; Devineau, S.; Aude, J. C.; Lagniel, G.; Chédin, S.; Legros, V.; Mathon, M. H.; Renault, J. P.; Pin, S.; Boulard, Y.; et al. Structural Determinants for Protein Adsorption/non-Adsorption to Silica Surface. PLoS One 2013, 8 (11), 1-13.

(45) Vertegel, A. A.; Siegel, R. W.; Dordick, J. S. Silica Nanoparticle Size Influences the Structure and Enzymatic Activity of Adsorbed Lysozyme. Langmuir 2004, 20, 6800-6807.

(46) Cukalevski, R.; Lundqvist, M.; Oslakovic, C.; Linse, S.; Cedervall, T. Structural Changes in Apolipoproteins Bound to Nanoparticles. Langmuir 2011, 27, 14360-14369.

(47) Devineau, S.; Zanotti, J. M.; Loupiac, C.; Zargarian, L.; Neiers, F.; Pin, S.; Renault, J. P. Myoglobin on Silica: A Case Study of the Impact of Adsorption on Protein Structure and Dynamics. Langmuir 2013, 29 (44), 13465-13472.

(48) Lundqvist, M.; Nygren, P.; Jonsson, H.; Broo, K. Induction of Structure and Function in a Designed Peptide upon Adsorption on a Silica Nanoparticle. Angew. Chemie - Int. Ed. 2006, 45, 8169-8173.

(49) Kim, J.; Grate, J. W.; Wang, P. Nanostructures for Enzyme Stabilization. Chem. Eng. Sci. 2006, 61 (3), 1017-1026.

(50) Gupta, M. N.; Kaloti, M.; Kapoor, M.; Solanki, K. Nanomaterials as Matrices for Enzyme Immobilization. Artif. Cells, Blood Substitutes Biotechnol. 2011, 39 (2), 98-109.

(51) Cipolatti, E. P.; Silva, M. J. A.; Klein, M.; Feddern, V.; Feltes, M. M. C.; Oliveira, J. V.; Ninow, J. L.; De Oliveira, D. Current Status and Trends in Enzymatic Nanoimmobilization. J. Mol. Catal. B Enzym. 2014, 99, 56-67.

(52) Fischer, N. O.; McIntosh, C. M.; Simard, J. M.; Rotello, V. M. Inhibition of Chymotrypsin through Surface Binding Using Nanoparticle-Based Receptors. Proc Natl Acad Sci U S A 2002, 99 (8), 50185023.

(53) Pandey, P.; Singh, S. P.; Arya, S. K.; Gupta, V.; Datta, M.; Singh, S.; Malhotra, B. D. Application of Thiolated Gold Nanoparticles for the Enhancement of Glucose Oxidase Activity. Langmuir 2007, 23 (6), 3333-3337.

(54) Drobny, G. P.; Long, J. R.; Shaw, W. J.; Cotten, M.; Stayton, P. S. Structure and Dynamics of 
Proteins Adsorbed to Biomaterial Interfaces. Encycl. Magn. Reson. 2007, 1-11.

Czeslik, C.; Royer, C.; Hazlett, T.; Mantulin, W. Reorientational Dynamics of Enzymes Adsorbed on Quartz: A Temperature-Dependent Time-Resolved TIRF Anisotropy Study. Biophys. J. 2003, 84 (4), 2533-2541.

(56) Motzkus, C.; Gaie-Levrel, F.; Ausset, P.; Maille, M.; Baccile, N.; Vaslin-Reimann, S.; Idrac, J.; Oster, D.; Fischer, N.; Mace, T. Impact of Batch Variability on Physicochemical Properties of Manufactured TiO2 and SiO2 Nanopowders. Powder Technol. 2014, 267, 39-53.

(57) Schrurs, F.; Lison, D. Focusing the Research Efforts. Nat. Nanotechnol. 2012, 7 (9), 546-548.

(58) Perutz, M. F. Preparation of Haemoglobin Crystals. J. Cryst. Growth 1968, 2 (1), 54-56.

(59) Jelkmann, W.; Baufer, C. What Is the Best Method to Remove 2,3-Diphosphoglycerate from Hemoglobin? Anal. Biochem. 1976, 75 (2), 382-388.

(60) Antonini, E.; Brunori, M. Hemoglobin and Myoglobin in Their Interactions with Ligands. Frontiers of Biology; North Holland Publishing Company, 1971.

(61) Krause, E.; Beyermann, M.; Dathe, M.; Rothemund, S.; Bienert, M. Location of an Amphipathic Alpha-Helix in Peptides Using Reversed-Phase HPLC Retention Behavior of D-Amino Acid Analogs. Anal. Chem. 1995, 67 (2), 252-258.

(62) Böhm, G.; Muhr, R.; Jaenicke, R. Quantitative Analysis of Protein Far UV Circular Dichroism Spectra by Neural Networks. Protein Eng. 1992, 5 (3), 191-195.

(63) Giardina, B.; Amiconi, G. Measurement of Binding of Gaseous and Non Gaseous Ligands to Hemoglobins by Conventional Spectrophotometric Procedures. Methods Enzymol. 1981, 76, 417427.

(64) Langmuir, I. The Adsorption of Gases on Plane Surfaces of Glass, Mica and Platinum. J. Am. Chem. Soc. 1918, 40, 1361-1403.

(65) Johnson, R. D.; Arnold, F. H. The Temkin Isotherm Describes Heterogeneous Protein Adsorption. Biochim. Biophys. Acta (BBA)/Protein Struct. Mol. 1995, 1247 (2), 293-297.

(66) Mura-Galelli, M. J.; Voegel, J. C.; Behr, S.; Bres, E. F.; Schaaf, P. Adsorption/desorption of Human Serum Albumin on Hydroxyapatite: A Critical Analysis of the Langmuir Model. Proc. Natl. Acad. Sci. U. S. A. 1991, 88 (13), 5557-5561.

(67) Latour, R. A. The Langmuir Isotherm: A Commonly Applied but Misleading Approach for the Analysis of Protein Adsorption Behavior. J. Biomed. Mater. Res. - Part A 2015, 103 (3), 949-958.

(68) Zhuravlev, L. T. The Surface Chemistry of Amorphous Silica. Zhuravlev Model. Colloids Surfaces A Physicochem. Eng. Asp. 2000, 173 (1-3), 1-38.

(69) Patwardhan, S. V.; Emami, F. S.; Berry, R. J.; Jones, S. E.; Naik, R. R.; Deschaume, O.; Heinz, H.; Perry, C. C. Chemistry of Aqueous Silica Nanoparticle Surfaces and the Mechanism of Selective Peptide Adsorption. J. Am. Chem. Soc. 2012, 134 (14), 6244-6256.

(70) Brown, M. A.; Goel, A.; Abbas, Z. Effect of Electrolyte Concentration on the Stern Layer Thickness at a Charged Interface. Angew. Chemie - Int. Ed. 2016, 55 (11), 3790-3794.

(71) Katz, D. S.; White, S. P.; Huang, W.; Kumar, R.; Christianson, D. W. Structure Determination of Aquomet Porcine Hemoglobin at 2.8 A Resolution. J. Mol. Biol. 1994, 244, 541-553.

(72) Meissner, J.; Prause, A.; Bharti, B.; Findenegg, G. H. Characterization of Protein Adsorption onto Silica Nanoparticles: Influence of pH and Ionic Strength. Colloid Polym. Sci. 2015, 293 (11), 33813391.

(73) Devineau, S.; Mathé, C.; Legros, V.; Gonnet, F.; Daniel, R.; Renault, J. P.; Pin, S. The Nano-Bio Interface Mapped by Oxidative Footprinting of the Adsorption Sites of Myoglobin. Anal. Bioanal. Chem. 2014, 406 (30), 8037-8040.

(74) Billsten, P.; Wahlgren, M.; Arnebrandt, T.; McGuire, J.; Elwing, H. Structural Changes of T4 Lysozyme upon Adsorption to Silica Nanoparticles Measured by Circular Dichroism. J. Colloid Interface Sci. 1995, 175, 77-82.

(75) Shen, X.-C.; Liou, X.-Y.; Ye, L.-P.; Liang, H.; Wang, Z.-Y. Spectroscopic Studies on the Interaction between Human Hemoglobin and CdS Quantum Dots. J. Colloid Interface Sci. 2007, 311 (2), 400406. 
(76) Mahato, M.; Pal, P.; Tah, B.; Ghosh, M.; Talapatra, G. B. Study of Silver Nanoparticle-Hemoglobin Interaction and Composite Formation. Colloids Surfaces B Biointerfaces 2011, 88 (1), 141-149.

(77) Choy, N.; Raussens, V.; Narayanaswami, V. Inter-Molecular Coiled-Coil Formation in Human Apolipoprotein E C-Terminal Domain. J. Mol. Biol. 2003, 334 (3), 527-539.

(78) Yonetani, T.; Laberge, M. Protein Dynamics Explain the Allosteric Behaviors of Hemoglobin. Biochemistry 2008, 1784, 1146-1158.

(79) Hewitt, J. A.; Kilmartin, J. V; Eyck, L. F.; Perutz, M. F. Noncooperativity of the Alpha Beta Dimer in the Reaction of Hemoglobin with Oxygen. Proc Natl Acad Sci U S A 1972, 69 (1), 203-207.

(80) Condo, S. G.; Corda, M.; Sanna, M. T.; Pellegrint, M. G.; Ruiz, M. P.; Castagnola, M.; Giardina, B. Molecular Basis of Low-Temperature Sensitivity in Pig Hemoglobins. Eur. J. Biochem. 1992, 209, 773-776.

(81) Fushitani, K.; Riggs, A. F. The Extracellular Hemoglobin of the Earthworm, Lumbricus Terrestris: Oxygenation Properties of Isolated Chains, Trimer, and a Reassociated Product. J. Biol. Chem. 1991, 266 (16), 10275-10281.

(82) Venkatesh, B.; Miyazaki, G.; Imai, K.; Morimoto, H.; Hori, H. Oxygen Equilibrium and EPR Studies on alphalbeta1 Hemoglobin Dimer. J. Biochem. 2004, 136, 595-600.

(83) Laberge, M.; Kövesi, I.; Yonetani, T.; Fidy, J. R-State Hemoglobin Bound to Heterotropic Effectors: Models of the DPG, IHP and RSR13 Binding Sites. FEBS Lett. 2005, 579 (3), 627-632.

(84) Lundqvist, M.; Sethson, I.; Jonsson, B. H. Transient Interaction with nanoparticles "Freezes" a Protein in an Ensemble of Metastable near-Native Conformations. Biochemistry 2005, 44 (30), 10093-10099.

(85) Kondo, A.; Mihara, J. Comparison of Adsorption and Conformation of Hemoglobin and Myoglobin on Various Inorganic Ultrafine Particles. J. Colloid Interface Sci. 1996, 177 (1), 214-221.

(86) Shimizu, K.; Amano, T.; Bari, M. R.; Weaver, J. C.; Arima, J.; Mori, N. Glassin, a Histidine-Rich Protein from the Siliceous Skeletal System of the Marine Sponge Euplectella, Directs Silica Polycondensation. Proc. Natl. Acad. Sci. 2015, 112 (37), 11449-11454.

(87) Cocco, M. J.; Kao, Y. H.; Phillips, A. T.; Lecomte, J. T. Structural Comparison of Apomyoglobin and Metaquomyoglobin: $\mathrm{pH}$ Titration of Histidines by NMR Spectroscopy. Biochemistry 1992, 31 (28), 6481-6491.

(88) Isom, D. G.; Castañeda, C. A.; Cannon, B. R.; García-Moreno, B. Large Shifts in pKa Values of Lysine Residues Buried inside a Protein. Proc. Natl. Acad. Sci. U. S. A. 2011, 108 (13), 5260-5265.

(89) Myalitsin, A.; Urashima, S.; Nihonyanagi, S.; Yamaguchi, S.; Tahara, T. Water Structure at the Buried Silica/Aqueous Interface Studied by Heterodyne-Detected Vibrational Sum-Frequency Generation. J. Phys. Chem. C 2016, 120, 9357-9363.

(90) Rimola, A.; Costa, D.; Sodupe, M.; Ugliengo, P. Silica Surface Features and Their Role in the Adsorption of Biomolecules.pdf. Chem. Rev. 2013, 113, 4216-4313.

(91) Sire, O.; Zentz, C.; Pin, S.; Chinsky, L.; Turpin, P.; Martel, P.; Wong, P. T. T.; Alpert, B.; Kh, O. Long-Range Effects in Liganded Hemoglobin Investigated by Neutron and UV Raman Scattering, FTIR, and CD Spectroscopies. J. Am. Chem. Soc. 1997, 119, 12095-12099.

(92) Kondo, A.; Fukuda, H. Effects of Adsorption Conditions on Kinetics of Protein Adsorption and Conformational Changes at Ultrafine Silica Particles. J. Colloid Interface Sci. 1998, 198, 34-41.

(93) Arnone, A. X-Ray Diffraction Study of Binding of 2,3-Diphosphoglycerate to Human Deoxyhemoglobin. Nature 1972, 237, 146-149.

(94) Richard, V.; Dodson, G. G.; Mauguen, Y. Human Deoxyhemoglobin-2,3-Diphosphoglycerate Complex Low Salt Structure at 2.5 Angstrom Resolution. J. Mol. Biol. 1993, 233, 270-274.

(95) Imai, K. Allosteric Effects in Haemoglobin; Cambridge University Press, Ed.; 1982.

(96) Tsuneshige, A.; Kanaori, K.; Samuni, U.; Danstker, D.; Friedman, J. M.; Neya, S.; Giangiacomo, L.; Yonetani, T. Semihemoglobins, High Oxygen Affinity Dimeric Forms of Human Hemoglobin Respond Efficiently to Allosteric Effectors without Forming Tetramers. J. Biol. Chem. 2004, 279 (47), 48959-48967.

(97) Hallaway, B. E.; Hallaway, P. E.; Tisel, W. A.; Rosenberg, A. Changes in Conformation and 
Function of Hemoglobin and Myoglobin Induced by Adsorption to Silica. Biochem. Biophys. Res. Commun. 1979, 86, 689-696.

(98) Franchi, D.; Fronticelli, C.; Bucci, E. Folding Domains as Functional Tools in Allosteric Systems: A Heme-Dependent Domain in Hemoglobin Beta Subunits. Biochemistry 1982, 21 (0006-2960), 6181-6187.

(99) Monod, J.; Wyman, J.; Changeux, J. P. On the Nature of Allosteric Transitions: A Plausible Model. J. Mol. Biol. 1965, 12, 88-118.

(100) Perutz, M. F.; Wilkinson, A. J.; Paoli, M.; Dodson, G. G. The Stereochemical Mechanism of the Cooperative Effects in Hemoglobin Revisited. Annu. Rev. Biophys. Biomol. Struct. 1998, 27, 1-34.

(101) Yonetani, T.; Kanaori, K. How Does Hemoglobin Generate Such Diverse Functionality of Physiological Relevance? Biochim. Biophys. Acta - Proteins Proteomics 2013, 1834 (9), 18731884. 


\section{TABLE OF CONTENT GRAPHIC}

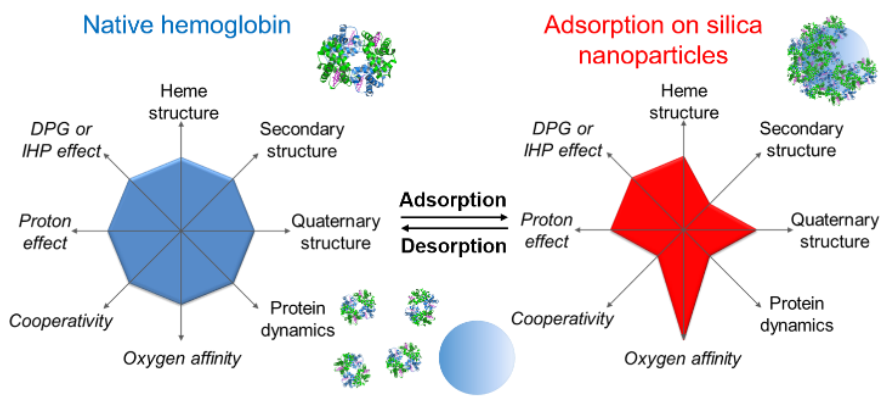

